\title{
PENYULUHAN PEMASARAN PRODUK KERAJINAN TANGAN TRADISIONAL ANYAM-ANYAMAN DI DESA BATU JONG-JONG KECAMATAN BAHOROK KABUPATEN LANGKAT
}

\author{
Yayuk Yuliana, SE, M.Si \\ Universitas Muslim Nusantara Al-Washliyah \\ Jl. Garu II No. 93 Kampus A Medan \\ yayuk.yuliana14@gmail.com
}

\begin{abstract}
Abstrak
Pengabdian pada Masyarakat ini bertujuan untuk memberikan wawasan pengetahuan mengenai pemahaman kepada masyarakat dengan melibatkan perempuan di sekitar kawasan Taman Nasional Gunung Leuiser secara partisipatif dan berkelanjutan dalam produksi dan pemasaran kerajinan tangan anyam-anyaman dengan menajamen yang baik di dusun batu katak, desa batu jong-jong, kecamatan bahorok, kabupaten Langkat. Metode pengabdian masyarakat, langsung dengan melakukan penyuluhan di rumah warga dengan kondisi informal dinilai lebih efektif. Pamaparan materi dengan berdialog dan memberikan perbandingan tempat atau kelompok lain yang sudah berhasil, memberikan wawasan yang baru bagi anggota lembaga. Masyarakat akan lebih berani menyampaikan keluhan dan permasalahan yang dihadapi dalam pemasaran hasil kerajinan tangan berupa anyam-anyaman. Hasil Kegiatan pelatihan menunjukkan tanggapan yang sangat baik dari masyarakat dengan adanya respon yang positif dari masyarakat dilihat dari inovasi yang mereka hasilkan atas produksi anyam-anyaman yang mereka hasilkan. Pemasaran dengan memanfaatkan internet memberikan harapan besar bagi masyarakat untuk dapat menduniakan produk kerajinan tradisional anyamanyaman yang unik dan ramah lingkungan.
\end{abstract}

Kata kunci : kerajinan tangan tradisional, desa batu jong-jong, pemasaran

\begin{abstract}
Community Service aims to provide insight into the understanding of knowledge to the community by involving women in the vicinity of Gunung Leuiser National Park in a participatory and sustainable manner in the production and marketing of wicker handicrafts with good menagament in Dusun Batu Katak, Batu jong-jong village , bahorok sub-district, Langkat Regency. Method of community service, directly by doing counseling at home of citizens with informal condition is considered more effective. Material is delivered by using dialogue and provide a comparison of other places or groups that have been successful, providing new insights for members of the institution. The community will be more courageous to convey the complaints and problems faced in the marketing of handicraft products such as plaiting. Outcomes The training activities showed an excellent response from the community with a positive response from the community viewed from the innovations they generate on the production of the anyam anyaman they produced. Marketing by utilizing the internet gives great hope for
\end{abstract}


the community to be able to empower the traditional craft products of anyam anyaman that are unique and environmentally friendly.

Keywords: traditional handicraft, Batu jong-jong stone village, marketing

\section{PENDAHULUAN}

Desa Batu Jong-Jong merupakan salah satu desa yang langsung berbatasan dengan Taman Nasional Gunung Leuser (TNGL). Menurut pengakuan masyarakat, bahwa dulu di desa ini banyak pelaku Illegal Logging. Saat ini aktivitas itu sudah bisa dikatakan tidak ada lagi di desa Batu JongJong, masyarakat desa Batu JongJong sudah menyadari akan bahaya yang mengancam apabila aktivitas illegal tersebut tetap dilakukan. Pada bulan Mei tahun 2013 dibentuk Lembaga Pariwisata Batu Katak (LPBK) sebagai wadah bagi masyarakat untuk mengembangkan potensi alam dan kekayaan flora dan fauna di dusun Batu Katak sebagai daerah ekowisata.

Kondisi hutan di Batu Katak masih sangat bagus, tetapi berada di luar kawasan TNGL, sehingga ini merupakan peluang yang sangat baik untuk pengembangan ekowisata dengan jaminan bahwa kawasan TNGL tetap akan terjaga. Sungai Bekail dan belasan goa kapur sangat menarik minat wisatawan baik domestik maupun asing. Flora dan fauna yang terdapat di dalam kawasan TNGL juga masih terdapat di hutan di luar kawasan di dusun Batu Katak. Pada tahun 2014 tercatat 10.000 wisatawan domestik dan 400 wisatawan asing, JanuariPebruari 2015 tercatat 319 wisatawan domestik dan 120 wisatawan asing.

Total keseluruhan anggota LPBK sebanyak 30 orang dengan berbagai profesi saat ini sebagian anggota sudah menjadi pemandu wisata. Usaha yang sudah dijalankan adalah pembangunan penginapan dan rumah makan sederhana (warung nasi), pembuatan demplot tanaman obat, penanaman pohon, dan pembuatan kerajinan tangan berupa anyaman. Kerajinan tangan berupa anyaman dilakukan oleh kaum perempuan, hasil kerajinan tangan diharapkan dapat menjadi komoditi yang bisa dipasarkan sebagai souvenir.

Pengembangan kerajinan tangan berupa anyaman akan dikembangkan sebagai usaha yang mendukung pengembangan ekowisata, kaum pria menjadi pemandu dan kaum perempuan memiliki usaha kerajinan tangan. Pada masa mendatang diharapkan kerajinan tangan berupa anyaman dan produk lain akan menjadi ciri khas dari desa Batu Jong-Jong. Hutan lestari masyarakat sejahtera merupakan cita-cita dari LPBK, kelestarian TNGL dan hutan di Batu Jong-Jong merupakan amanah yang harus dijaga, kesejahteraan masyarakat merupakan cita-cita luhur warga masyarakat desa Batu Jong-Jong.

Pada tahun 2014 desa Batu Jong-Jong menjadi Model Desa Konservasi yang dibina oleh BBTNGL. Fasilitasi dari Pusat Penyuluhan Kehutanan diharapkan dapat membantu pengembangan kerajinan tangan berupa anyaman dengan bahan baku dari pandan, mbilo ( kulit kayu) dan rotan sebagai souvenir di ekowisata Batu Katak. 
UMN Al Washliyah melalui Fakultas Ekonomi berusaha menjadi media untuk memberikan penyuluhan pemasaran kerajinan tangan anyam-anyaman dengan menajamen yang baik melalui program pengabdian masyarakat. Kegiatan ini diharapkan mampu untuk meningkatkan kualitas masyarakat dalam memasarkan hasil kerajinan tangan anyam-anyaman mereka sehingga dikenal sampai keluar daerah yang berdampak meningkatkan pendapatan penghasilan masyarakat

\section{TARGET DAN LUARAN}

\subsection{Target}

Target yang diharapkan dalam Program Pengabdian Masyarakat berbasis Ipteks bagi Masyarakat (IbM) adalah:

1. Pemberdayaan masyarakat dengan melibatkan perempuan di sekitar kawasan TNGL yang bersifat konservatif

2. Ekonomi produktif untuk menambah pendapatan masyrakat di desa sekitar kawasan

3. Memberikan keterampilan dan pengetahuan yang baru kepada masyarakat tentang pemasaran produk tradisional kerajinan tangan anyamanyaman.

\subsection{Luaran}

Luaran yang akan dicapai
dalam Program Pengabdian
Masyarakat berupa:
1.Seminar hasil dari pengabdian
masyarakat serta publikasi ilmiah
pada jurnal nasional.
2.Laporan Pengabdian.

\section{METODE}

\subsection{Metode Pelaksanaan.}

Metode pengabdian
masyarakat, langsung $\begin{array}{r}\text { dengan } \\ \text { melakukan penyuluhan di rumah }\end{array}$
warga dengan kondisi informal dinilai lebih efektif. Pamaparan materi dengan berdialog dan memberikan perbandingan tempat atau kelompok lain yang sudah berhasil memberikan wawasan yang baru bagi anggota lembaga. Masyarakat akan lebih berani menyampaikan keluhan dan permasalahan yang dihadapi dalam pemasaran hasil kerajinan tangan berupa anyam-anyaman.

Aspek produksi sudah dirasakan cukup, karena memang sudah diajarkan secara turun temurun. Pemasaran ke luar daerah masih menjadi kendala karena keterbatasan sarana dan asilitas pendukung. Saat ini jaringan telekomunikasi di Batu Katak masih terbatas pada satu operator saja, itupun kondisinya masih dinilai lemah. Pemasaran masih dilakukan dari mulut ke mulut dan lebih cenderung kekeluargaan.

Pemasaran

dengan memanfaatkan internet memberikan harapan besar bagi masyarakat untuk dapat menduniakan produk kerajinan tradisional anyam-anyaman yang unik dan ramah lingkungan. Harganya yang masih sangat murah bisa ditingkatkan melalui peningkatan jumlah produksi dan mencari peluang pasar di luar Batu Katak bahkan pada skala nasional.

Berkembangnya Ekowisata

Batu Katak merupakan salah satu peluang untuk membuka jaringan komunikasi dan jaringan pemasaran dengan pihak luar. Wisatawan nusantara dan wisatawan mancanegara sudah mulai meminati 
produk tradisional kerajinan tangan anyam-anyaman. Hal ini bisa berjalan beriringan karena Ekowisata Batu Katak mengandalkan panorama alam dan tradisi yang unik.

Dalam waktu secepatnya perlu dibuat sebuah toko atau gerai yang memajang semua produk tradisional hasil masyarakat Batu Katak. Para wisatawan dapat membeli langsung maupun memesan dalam skala besar. Pemasaran menjadi kunci utama dalam keberhasilan mengembangkan produk tradisional.

\section{Pelaksanaan Kegiatan}

\subsection{Hasil Capaian}

Hasil yang sudah dicapai dalam Pengabdian Masyarakat berbasis Ipteks bagi Masyarakat (IbM) adalah:

1. Bersosialisasi dengan masyarakat terutama ibu-ibu dengan memberikan pelatihan manajemen pemasaran dan pengembangan usaha kerajinan tangan anyamanyaman

2. Menyiapkan peralatan dan pelaksanaan penyuluhan sesuai dengan koordinasi.

Gambar 1. Produk Kerajinan Tangan

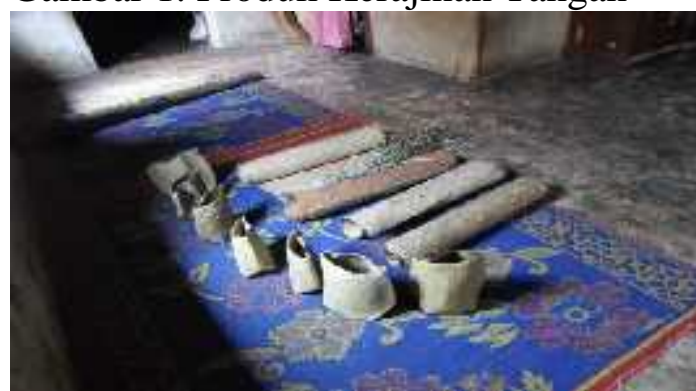

Gambar 2. Lokasi Pelaksanaan Kegiatan IbM

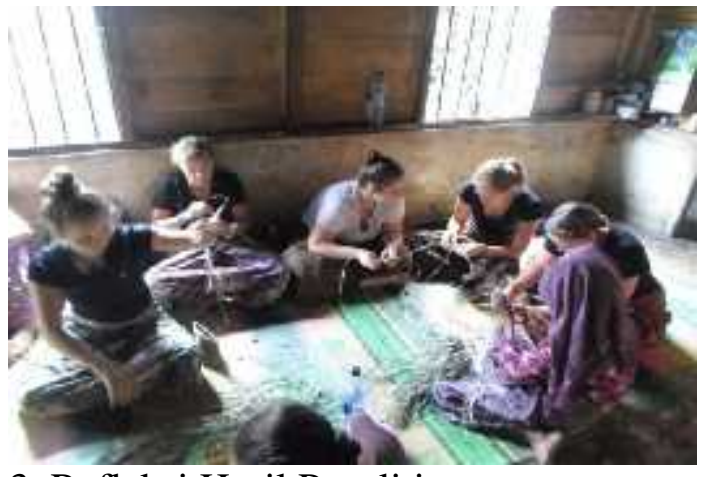

3. Refleksi Hasil Penelitian

Selama proses penyuluhann tim pelaksana kegiatan pengabdian melakukan dialog dan diskusi kepada para peserta penyuluhan. Secara umum masyarakat terutama ibu-ibu mengatakan penyuluhan ini sangat bermanfaat bagi mereka.

\subsection{Luaran yang Dicapai}

Luaran yang dicapai pada pelaksanaan IbM ini adalah:

1 Masyarakat mampu berinovasi dalam mengkreasikan hasil kerajinan tangan anyamanyaman.

2 Menjalian mitra dengan agen perjalanan dan beberapa tempat titipan penjualan barang kerajinan tangan di sekitar daerah ekowisata batu katak.

\section{RENCANA TAHAPAN BERIKUTNYA}

Tahapan pelaksanaan pengabdian yang telah dilaksanakan sampai saat ini berada ditahapan penyuluhan fasilitasi Percontohan Pemberdayaan Masyarakat Desa Hutan Konservasi yang kami susun. Pada rencana ini masih kurang sempurna, besar harapan kami kegiatan ini dapat dilaksanakan dengan baik, berbagai kekurangan dalam usulan kegiatan ini dapat dilengkapi dalam pelaksanaan nantinya. Hasil yang diharapkan 
pada tahap ini adalah masyarakat mengetahui cara memasarkan produk hasil kerajinan dan manejemn produksi yang baik sehingga mampu meningkatkan pendapatan masyarakat. Pada tahapan berikutnya adalah pengembangan inovasi produk kerajinan tangan anyamanyaman.

\section{KESIMPULAN DAN SARAN 6.1.Kesimpulan}

Kegiatan pengabdian Ipteks bagi Masyarakat (IbM) yang telah dilakukan berupa penyuluhan manajemen pemasaran hasil kerajinan tangan anyam-anyaman di dusun batu kata desa batu jong-jong. Pelatihan diawali dengan Fasilitasi Percontohan Pemberdayaan Masyarakat Desa Hutan Konservasi. Dari hasil diskusi dengan kepala Desa dan masyarakat sekitar selama pelaksanaan pengabdian, mereka sangat bersemangat dan berharap ada pelatihan-pelatihan

\subsection{Saran}

Adanya keberlanjutan dari program pengabdian berupa kerjasama dalam pelatihan keterampilan pemberdayaan perempuan untuk meningkatkan pendapatan keluarga

\section{DAFTAR PUSTAKA}

[BBTNGL] Balai Besar Taman Nasional Gunung Leuser. 2011. Dokumen Zonasi Balai Besar Taman Nasional Gunung Leuser Tahun 2011. BBTNGL.Medan.

Dewi, L. G. L. K. 2013. Usaha Pemberdayaan Sosial Ekonomi Masyarakat Desa Beraban Dalam Pengelolaan Tanah Lot Secara Berkelanjutan. Analisa Pariwisata. 13 (1) : 32-44.
Purnomo, H., Sulistyantara, B., dan Gunawan, A. 2013. Peluang Usaha Ekowisata di Kawasan Cagar Alam Pulau Sempu, Jawa Timur. Jurnal Penelitian Sosial Dan Ekonomi Kehutanan. 10 (4) : 247-263.

Rahmawaty and Rauf, A. 2011. Utilization of Land in Old Rubber Plantation At Gunung Leuser National Park, Indonesia. Science Journal of Agricultural Research and Management .12 : 2-6.

Suryawan, I, B. 2013. Pengelolaan Potensi Ekowisata Di Desa Cau Balayu, Kecamatan Marga, Kabupaten Tabanan. Analisa Pariwisata. 13 (1) : 106-111. 